\title{
PENGAMBILAN KEPUTUSAN INOVASI TEKNOLOGI INSTORE DRYER BAWANG PUTIH DI DESA TUWEL, KECAMATAN BOJONG, KABUPATEN TEGAL
}

\section{The decision making of Innovation Technology for Garlic Comodity in Tuwel Village, Bojong District, Tegal Regency}

\author{
Nabila Nadia Rahma*) Dwi Sadono dan Endang Sri Wahyuni \\ Departemen Sains Komunikasi dan Pengembangan Masyarakat, Fakultas Ekologi Manusia, \\ Institut Pertanian Bogor, Dramaga Bogor 16680, Indonesia \\ ${ }^{*}$ E-mail: nadiarahmanabila@gmail.com
}

\section{ABSTRACT}

The development of agricultural innovation as support for Indonesia's agricultural potential continues to be created and introduced, one of them is the Instore Dryer Technology. The Instore Dryer technology is an innovative garlic harvest dryer. Farmers as recipients of innovation need to be encouraged to adopt innovations, both from internal and external factors. There are five processes in making decisions on the adoption of innovation in farmers, from the stage of introducing the innovation to the stage of confirming the adoption of innovation. The purpose of this study was to analyze the factors related to the farmer adoption decision-making process. The factors analyzed were individual characteristics, the role of agricultural extension agents, and the five stages of innovation adoption. This research was conducted using quantitative and qualitative methods. The results of this study indicate that the role of agent extentions have a relation with the stages of of innovation adoption decision making and every stages of innovation adoption decision making have a significant relations.

Keywords: Adoption, Instore dryer technology, The role of agentof extentions

\begin{abstract}
ABSTRAK
Perkembangan inovasi pertanian sebagai penunjang potensi pertanian Indonesia terus diciptakan dan diperkenalkan, salah satunya adalah Teknologi Instore Dryer. Teknologi Instore Dryer adalah inovasi pengering hasil panen bawang putih. Petani selaku penerima inovasi perlu mendapat dorongan agar dapat melakukan adopsi inovasi, baik dari faktor internal maupun faktor eksternal. Terdapat limaproses dalam pengambilan keputusan adopsi inovasi pada petani, dari tahap pengenalan inovasi hingga tahap konfirmasi adopsi inovasi. Tujuan dari penelitian ini untuk menganalisis faktor-faktor yang berhubungan dengan proses pengambilan keputusan adopsi petani. Faktor yang dianalisis adalah karakteristik individu, peran penyuluh pertanian, dan lima tahap adopsi inovasi. Penelitian ini dilakukan dengan metode kualitatif dan kuantitatif. Hasil penelitian ini menunjukkan intensitas penyuluhan petani berhubungan dengan tahap pengenalan inovasi, peran penyuluh berhubungan dengan tahap pengambilan keputusan, dan lima tahap pengambilan keputusan adopsi inovasi memiliki hubungan yang signifikan antar tahapannya.
\end{abstract}

Kata Kunci: Adopsi, Peran penyuluh, Teknologi instore dryer. 


\section{PENDAHULUAN}

Bawang putih (Allium sativum L) merupakan komoditas pangan penting bagi masyarakat. Bawang putih termasuk ke dalam anggota bawang-bawangan yang paling populer di dunia, sehingga bawang putih sangat diperlukan untuk memenuhi berbagai kebutuhan seperti kebutuhan pangan dan kedokteran (Ulfa 2018). Namun, selama ini kenyataan yang ada di Indonesia, jumlah produksi bawang putih nasional selalu mengalami defisit untuk memenuhi kebutuhan konsumsi masyarakat. Tingginya konsumsi yang diikuti rendahnya produksi membuat pemerintah harus mengimpor bawang putih untuk mencukupi kebutuhan domestik setiap tahunnya. Berdasarkan data Kementerian Pertanian 2019, volume impor bawang putih sejak tahun 2012-2018 relatif mengalami peningkatan. Berdasarkan fakta tersebut, perlu adanya untuk meningkatkan ketersediaan bawang putih lokal dan menurunkan kuantitas bawang putih impor adalah mengaplikasikan berbagai macam inovasi untuk menunjang aktivitas usahatani bawang putih, dari inovasi penyediaan benih hingga teknologi pascapanen.

Teknologi Instore Dryer dapat membantu petani pada tahap pasca panen. Inovasi tersebut merupakan sebuah tempat pengeringan dan penyimpanan bawang yang dilengkapi dengan pengaturan suhu dan kelembaban sehingga dapat mengurangi tingkat susut bawang selama masa pengeringan (Badan Litbangtan 2017). Teknologi Instore Dryer mampu menekan kehilangan panen menjadi 16 persen dan menekan tingkat kerusakan selama penyimpanan di bawah 10 persen. Pengeringan yang sempurna menggunakan Instore Dryer dapat membantu petani untuk menghasilkan bibit bawang putih yang lebih berkualitas, sehingga dari hasil panen yang berkualitas tersebut akan mendorong kembali perbaikan kualitas dan produksi bawang putih pada level hulu. Teknologi Instore Dryer diharapkan dapat meningkatkan ketahanan mutu dan mengurangi tingkat kerusakan bawang putih melalui proses pelayuan dan pengeringan sehingga hasil panen bawang putih yang ada tidak menjadi hasil panen yang gagal dipasarkan kepada konsumen.

Teknologi Instore Dryer diluncurkan oleh Kementrian Pertanian melalui Badan Litbang Pertanian dihibahkan kepada Kelompok Tani Desa Tuwel, Kecamatan Bojong, Kabupaten Tegal sebagai suatu inovasi yang dapat diadopsi oleh petani setempat. Terdapat sejumlah petani yang telah memulai menggunakan Teknologi Instore Dryer. Hal ini mengindikasikan adanya respon petani yang cukup baik terhadap inovasi tersebut, namun pada faktanya masih terdapat petani yang belum mengaplikasikan Teknologi Instore Dryer. Soekarwati (1985) menyatakan bahwa beberapa hal penting dalam memengaruhi adopsi antara lain umur, pendidikan formal, pendidikan nonformal, jarak petani ke jalan utama, dan jarak petani ke lokasi. Adopsi teknologi bagi petani ditentukan oleh kebutuhan dan kesesuaian teknologi dengan kondisi biofisik, sosial, budaya, serta spesifik lokasi. Keputusan untuk mengadopsi ditentukan dari faktor internal dan eksternal petani (Aditiawati et al. 2014). Adopsi teknologi juga dipengaruhi oleh penyuluh pertanian yang dapat berperan sebagai motivator, komunikator, fasilitator, dan organisator (Putra et al. 2016).

Selain karakteristik internal petani, penyuluhan pertanian sangat diperlukan untuk mengubah pola pikir, sikap, dan perilaku guna mendorong petani memiliki persepsi positif terhadap inovasi teknologi pertanian yang ada untuk meningkatkan produktivitas pertanian serta membangun kehidupan petani yang lebih baik secara berkelanjutan. Adanya inovasi yang dikenalkan kepada petani, membutuhkan upaya dari penyuluh untuk mendukung adanya proses pengambilan keputusan adopsi inovasi, sehingga sangat penting untuk menganalisis bagaimana proses pengambilan keputusan petani terhadap inovasi Teknologi Instore Dryer.

\section{PENDEKATAN TEORITIS}

\section{Peran Penyuluh}

Mardikanto (2002) mengungkapkan seorang penyuluh harus seorang ahli pertanian yang berkompeten, di samping dapat berkomunikasi secara efektif dengan petani sehingga dapat 
mendorong minat belajar mereka dan harus berorientasi pada masalah yang dihadapi oleh petani. Penyuluh pertanian berperan dalam meningkatkan pengetahuan petani mengenai teknologi maupun informasi-informasi pertanian yang baru. Putra (2016), menyebutkan seorang penyuluh pertanian memiliki peran sebagai seorang fasilitator, motivator, komunikator, dan inovator.

\section{Adopsi Inovasi}

Rogers (2003) menyatakan adopsi teknologi pertanian juga merupakan suatu proses mental atau perubahan perilaku baik yang berupa pengetahuan (cognitive), sikap (affective), maupun keterampilan (psychomotor) pada diri seseorang sejak ia mengenal inovasi sampai memutuskan untuk mengadopsi setelah menerima inovasi. Jika persepsi adopter positif, inovasi teknologi tersebut cenderung lebih cepat diadopsi. Rogers (2003) juga mengemukakan seseorang akan dapat menerima atau menolak suatu inovasi jika telah melalui beberapa tahap, yaitu: 1) tahap pengetahuan (knowledge), 2) tahap persuasi (Persuasion, 3) tahap keputusan (Decisions), 4) tahap implementasi (Implementation, dan 5) tahap konfirmasi (Confirmation) Lima atribut karakteristik inovasi menurut Rogers (2003) terdiri dari: 1) keuntungan relatif (relative advantage), 2) kesesuaian (compability), 3) kerumitan (complexity), 4) kemungkinan dicoba (trialability), dan 5) kemungkinan diamati (observability).

\section{Karakteristik Petani}

Karakteristik individu merupakan faktor internal petani yang menggerakkan dan memengaruhi perilaku individu (Purba 2015). Ciri-ciri atau sifat-sifat yang dimiliki oleh petani meliputi beberapa faktor atau unsur-unsur yang melekat pada diri dapat diartikan sebagai karakteristik petani. Petani memiliki karakteristik yang beragam, hal tersebut dapat berupa karakter demografi, karakter sosial, dan karakter ekonomi petani itu sendiri. Karakter pada petani tersebutlah yang membedakan perilaku petani antara satu dengan lainnya.

\section{Teknologi Instore Dryer sebagai suatu Inovasi}

Fungsi teknologi Instore Dryer adalah sebagai alat bantu untuk pengeringan bawang putih yang sudah dipanen. Instore Dryer adalah bangunan penyimpanan dengan ukuran $6 \mathrm{~m}$ × $6 \mathrm{~m}$ x $2.5 \mathrm{~m}$ dapat menampung 6 ton bawang putih. Hasil penelitian Nugrahaet al. (2007) pada komoditas bawang merah menunjukkan bahwa sistem pengeringan bawang merah yang dilakukan di dalam gudang pengeringan dan penyimpanan (Instore Dryer) menunjukkan hasil yang sangat baik, proses pelayuan dan pengeringan dapat berlangsung cepat selama 3 hari dengan relative humidity antara 55-70 persen, tingkat kekeringan merata dan kualitas bawang yang dihasilkan cukup baik. Artinya pengeringan dengan Instore Dryer lebih cepat jika dibandingkan dengan menggunakan sinar matahari. Selain itu tidak menyebabkan kerusakan yang berarti, yaitu hanya berkisar antara 0.24-0.72 persen dibandingkan dengan penjemuran yang kerusakannya bisa mencapai $1.68 \%$.

\section{PENDEKATAN LAPANG}

\section{Metode Penelitian}

Penelitian ini merupakan penelitian dengan pendekatan kuantitatif yang didukung oleh data kualitatif untuk memperoleh data dan informasi yang dibutuhkan. Penelitian kuantitatif dilakukan dengan cara pengambilan data berupa angka yang diperoleh melalui metode survey yang menggunakan instrumen penelitian yang berbentuk angket/kuesioner terstruktur dari sampel yang diambil dari suatu populasi. Tujuan menggunakan metode kualitatif adalah untuk memahami permasalahan penelitian secara lebih mendalam danmenyeluruh.

\section{Lokasi dan Waktu Penelitian}

Penelitian ini dilakukan di Desa Tuwel, Kecamatan Bojong, Kabupaten Tegal, Jawa Tengah. Adapun pertimbangan penentuan desa lokasi penelitian adalah Desa Tuwel merupakan wilayah 
penghasil bawang putih yang dipilih sebagai wilayah percontohan Nasional untuk menerima bantuan Teknologi Instore Dryer (Amanda 2019)

\section{Jenis dan Teknik Pengumpulan Data}

Jenis data yang digunakan dalam penelitian ini adalah data primer dan data sekunder. Data primer didapatkan melalui wawancara terstruktur dengan bantuan kuesioner kepada responden. Sementara itu, data sekunder didapatkan melalui wawancara mendalam kepada informan yang memiliki informasi atau data tersebut. Selain itu data sekunder didapatkan dari hasil literatur, data BPS, maupun hasil-hasil penelitian sebelumnya.

\section{Teknik Penentuan Responden dan Informan}

Penelitian ini melibatkan dua subjek yaitu responden dan informan. Populasi penelitian ini adalah petani bawang putih yang tergabung dalam gabungan kelompok tani "Berkah Tani" di Desa Tuwel, Kecamatan Bojong, Kabupaten Tegal, Provinsi Jawa Tengah. Pemilihan responden dilakukan melalui metode pengambilan sampel simple random sampling melalui undian tabel angka acak. Jumlah responden dalam penelitian ini adalah 43 orang. Pemilihan informan dilakukan secara purposif dan snowball sampling. Informan dalam penelitian terdiri Petugas Penyuluh Lapangan di Desa Tuwel, Ketua Kelompok Tani yang mengetahui secara detail proses sosialisasi Teknologi Instore Dryer, Masyarakat Desa Tuwel yang bertempat tinggal tidak jauh dari tempat penyimpanan Teknologi Instore Dryer, dan responden terpilih yang telah mengenal Teknologi Instore Dryer.

\section{Teknik Pengolahan dan Analisis Data}

Data yang digunakan pada penelitian ini adalah data primer dan data sekunder yang diperoleh dengan menggunakan metode kuantitatif dan kualitatif. Aplikasi Microsoft Excel 2010 digunakan pada tahap penginputan data sehingga didapatkan tabel frekuensi setiap variabel. Aplikasi SPSS for Windows versi 22.0 digunakan untuk melakukan uji statistik data, yaitu uji korelasi Rank Spearman. Penelitian didukung dengan data kualitatif yang diperoleh melalui wawancara mendalam dan observasi lapang. Tahapan pengolahan data kualitatif adalah sebagai berikut: 1) reduksi data, 2) penyajian, 3) penarikan kesimpulan.

\section{HASIL DAN PEMBAHASAN}

\section{Kondisi Geografis dan Luas Wilayah}

Desa Tuwel merupakan satu dari 17 desa di Kecamatan Bojong Kabupaten Tegal Provinsi Jawa Tengah. Desa Tuwel menjadi pusat kecamatan karena letaknya yang strategis. Kecamatan Bojong memiliki wilayah yang terdiri dari daratan dan relatif berbukit-bukit dengan kemiringan tinggi mencapai antara 500-1103 di atas permukaan laut. Kondisi lahan Desa Tuwel mendukung masyarakat setempat untuk bertani padi, jagung, kacang tanah, ubi, bawang merah dan putih, berbagai cabai, dan tanaman hortikultura pada lahan pegunungan. Sejak tahun 80-an Desa Tuwel sudah menjadi sentra pertanian tanaman hortikultura Kabupaten Tegal karena kondisi iklim dan topografi. Hal ini yang menjadi pendukung bagi masyarakat Desa Tuwel berprofesi sebagai petani.

\section{Teknologi Instore Dryer Bawang Putih di Desa Tuwel}

Petani setempat lebih mengenal Teknologi Instore Dryer dengan sebutan "mesin pengering". Penggunaan Teknologi Instore Dryer digunakan untuk skala panen kelompok tani. Hal ini dikarenakan sistem jual hasil panen para petani Desa Tuwel adalah menjual hasil panen kepada kelompok tani dengan hasil panen basah. Hasil panen basah yang dijual kepada kelompok tani sebanyak 70\%, kemudian akan dijual kepada pelaku usaha yang bekerjasama dengan kelompok tani yang ada di Desa Tuwel. Adapun 30\% hasil panen lainnya untuk dikelola petani sendiri. Sejak Teknologi Instore Dryer resmi diberikan, penggunaannya ditujukan untuk pengeringan hasil panen kelompok saja, karena tidak adanya sistem pengelolaan untuk mengeringkan hasil 
panen pribadi milik petani. Pengeringan hasil panen diatur dan diawasi oleh petani yang menjadi pengurus pengelolaan Teknologi Instore Dryer. Sebagian besar anggota pengurus pengelola Teknologi Instore Dryer adalah pengurus Kelompok Tani Berkah Tani dan pengurus kelompok tani lainnya yang tergabung dalam kepengurusan Kantor Penangkar Benih Bawang Putih Berdikari Desa Tuwel. Hingga penelitian selesai dilakukan, baik pengurus kelompok tani maupun pengurus kantor penangkar benih belum membentuk sistem penggunaan Teknologi Instore Dryer untuk hasil panen pribadi petani karena belum adanya urgensitas yang berarti.

\section{KARAKTERISTIK PETANI}

Karakteristik petani yang diteliti meliputi: umur, tingkat pendidikan formal, intensitas mengikuti penyuluhan, luas penggunaan lahan, status kepemilikan lahan, tingkat pendapatan, dan sumber informasi sebagai pengukur tingkat kekosmopolitan petani.

Berdasarkan data pada Tabel 1, sebanyak 31 responden merupakan petani tergolong usia tidak muda, yaitu di atas 42 tahun. Terdapat 16 responden kategori usia dewasa dan 15 responden terkategori usia tua. Adapun 12 responden lainnya tergolong petani dengan usia muda, yaitu pada rentang usia 18-42 tahun. Tingkat pendidikan formal petani paling banyak tersebar di tingkat sedang (Tamat SMP/sederajat dan tamat SMA/sederajat). Mayoritas profesi rumah tangga di Desa Tuwel berlatar belakang sebagai petani, Dalam melakukan usahataninya, petani kerap mengikuti kegiatan penyuluhan yang rutin diadakan setiap bulan untuk menambah wawasan pertanian. Mayoritas petani memiliki frekuensi yang tinggi dalam mengikuti kegiatan penyuluhan. Petani setempat memiliki luas lahan yang beragam. Satuan luas lahan yang digunakan oleh petani setempat adalah bahu (bau), jika dikonversikan ke dalam satuan meter adalah 1 bau=7000 $\mathrm{m}^{2}$. Berdasarkan data, terdapat 9 responden menggunakan lahan yang tergolong luas, yaitu $\geq 4.419 \mathrm{~m}^{2}$. Status kepemilikan lahan yang dimiliki oleh mayoritas petani adalah lahan milik sendiri. Pendapatan paling tinggi petani Desa Tuwel adalah lebih dari 3.8 juta. Tingkat literasi petani untuk menambah informasi pertanian di Desa Tuwel masih sangatlah rendah, baik literasi tulisan cetak maupun literasi digital.

Tabel 1 Jumlah dan persentase responden berdasarkan karakteristik petani di Desa Tuwel tahun 2020

\begin{tabular}{llcc}
\hline \multicolumn{2}{c}{ Karakteristik Responden } & $\mathrm{n}$ & Responden \\
\hline Umur & $\begin{array}{l}\text { Muda } \\
(\leq 18-42 \text { tahun })\end{array}$ & 12 & 27.9 \\
& $\begin{array}{l}\text { Dewasa } \\
(43-55 \text { tahun }) \\
\text { Tua(>55 tahun })\end{array}$ & 16 & 37.2 \\
& 15 & 34.9 \\
\hline Total & & 43 & 100 \\
\hline
\end{tabular}




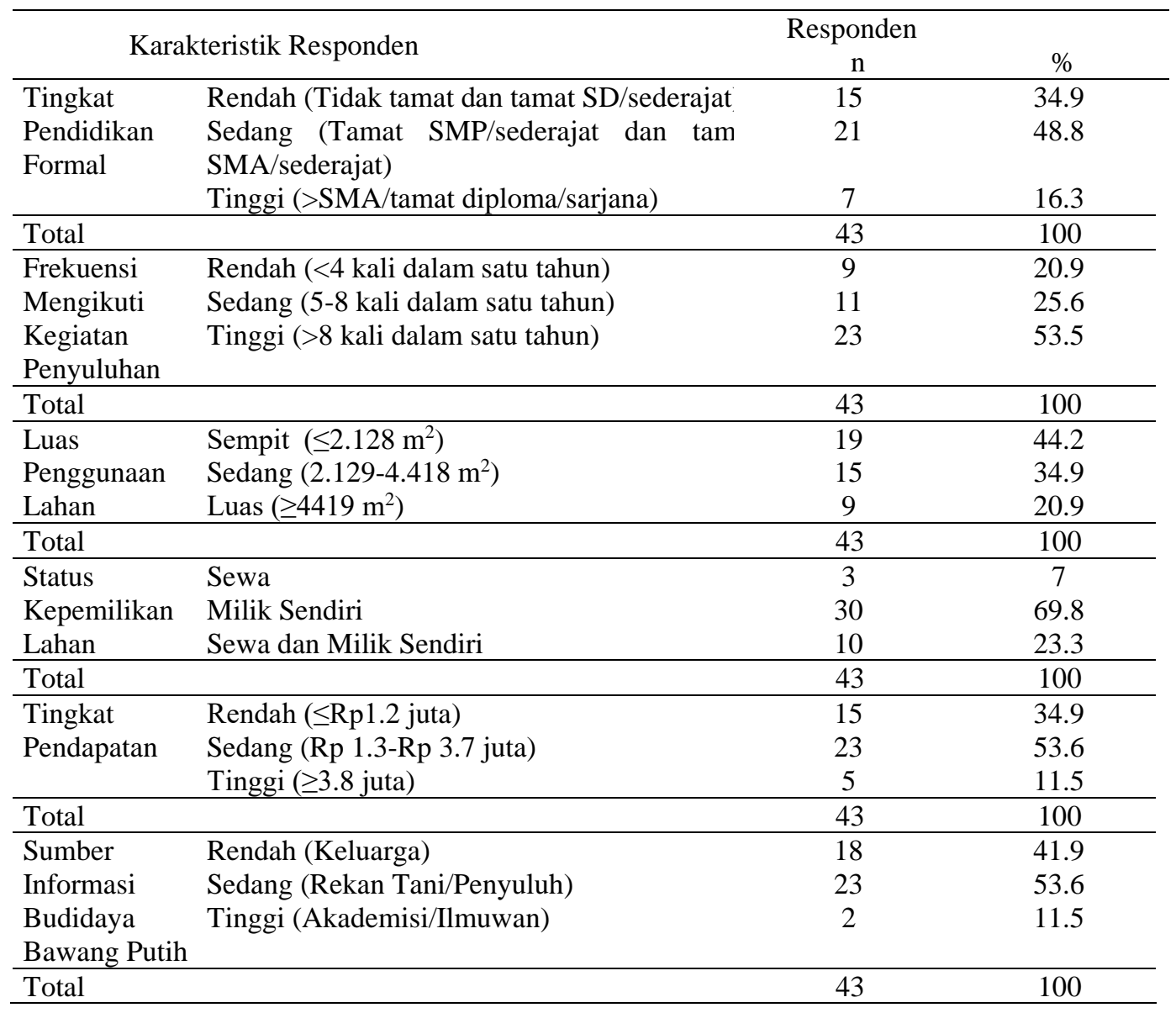

\section{KARAKTERISTIK INOVASI}

\section{Keuntungan Relatif}

Berdasarkan data pada Tabel 2, mayoritas petani (38 responden) menganggap dengan adanya Teknologi Instore Dryer dapat lebih menguntungkan petani. Salah satu keuntungan relatif yang paling dirasakan oleh petani antara lain adalah lebih singkatnya waktu yang dibutuhkan petani untuk mengeringkan.

Tabel 2 Jumlah dan persentase tingkat kesesuaian menggunakan Teknologi Instore Dryer di Desa Tuwel tahun 2020

\begin{tabular}{lcc}
\hline Keuntungan Teknologi Instore Dryer & $\mathrm{n}$ & $\%$ \\
\hline Kurang menguntungkan & 0 & 0 \\
Sama saja & 5 & 11.6 \\
Lebih menguntungkan & 38 & 88.4 \\
\hline Total & 43 & 100 \\
\hline
\end{tabular}

Kondisi iklim Desa Tuwel yang cenderung sejuk-dingin karena berada di dataran tinggi juga menjadikan Teknologi Instore Dryer sesuai jika diberikan kepada petani setempat. 


\section{Tingkat Kesesuaian}

Jumlah dan persentase responden berdasarkan tingkat kesesuaian Teknologi Instore Dryer disajikan pada Tabel 3.

Tabel 3 Jumlah dan persentase tingkat kesesuaian menggunakan Teknologi Instore Dryer di Desa Tuwel tahun 2020

\begin{tabular}{lcc}
\hline Tingkat Kesesuaian Teknologi & $\mathrm{n}$ & $\%$ \\
store Dryer & & 0 \\
Tidak sesuai & 0 & 62.8 \\
Sesuai & 27 & 37.2 \\
Sangat sesuai & 16 & 100 \\
\hline Total & 43 & \\
\hline
\end{tabular}

Sebanyak 27 responden menganggap Teknologi Instore Dryer sesuai dengan kondisi lingkungan setempat, cara mengeringkan hasil panen, kebutuhan petani setempat. Meskipun pengeringan menggunakan Teknologi Instore Dryer dilakukan dengan cara yang berbeda, akan tetapi tidak dianggap bertentangan dengan kebiasaan pengeringan sebelumnya. Jika sebelumnya menggunakan panas alami dari matahari, ketika menerapkan inovasi petani menggunakan panas yang dihasilkan oleh tungku pemanas.

\section{Tingkat Kerumitan}

Pada aspek tingkat kerumitan, mayoritas responden menganggap penggunaan Teknologi Instore Dryer lebih rumit (27 responden). Kerumitan yang dirasakan oleh mayoritas petani adalah cara penggunaan inovasi tersebut untuk hasil panen pribadi. Hal ini disebabkan Teknologi Instore Dryer dioperasikan, untuk mengeringkan hasil panen kelompok tani. Inovasi belum pernah dicoba untuk mengeringkan hasil panen pribadi petani dan hingga penelitian di lapang selesai. Jumlah dan persentase responden berdasarkan tingkat kerumitan dapat dilihat pada Tabel 4.

Tabel 4 Jumlah dan persentase tingkat kerumitan menggunakan Teknologi Instore Dryer di Desa Tuwel tahun 2020

\begin{tabular}{lcc}
\hline Tingkat Kerumitan Teknologi Instore Dryer & $\mathrm{n}$ & $\%$ \\
\hline Lebih mudah & 0 & 0 \\
Sama saja & 16 & 37.2 \\
Lebih rumit & 27 & 62.8 \\
\hline Total & 43 & 100 \\
\hline
\end{tabular}

\section{Tingkat Kemungkinan Dicoba dalam Skala Kecil}

Berdasarkan data pada tabel 5, mayoritas responden (69.8\%) memandang Teknologi Instore Dryer kurang mungkin dicoba dalam skala kecil. Kondisi lapang yang ditemui adalah petani membagi hasil panen nya menjadi 30 persen untuk sendiri dan 70 persen diberikan kepada kelompok tani, untuk dibeli oleh perusahaan (importir) secara panen basah atas kesepakatan kerjasama yang dibangun. Melalui kondisi tersebut, mesin Instore Dryer untuk selanjutnya dapat dialokasikan untuk mengeringkan hasil panen yang diterima kelompok tani. Hal tersebut mengakibatkan kurangnya kemungkinan Teknologi Instore Dryeruntuk dicoba dalam skala kecil. 
Tabel 5 Jumlah dan persentase kemungkinan Teknologi Instore Dryer dicoba dalam dalam skala kecil di Desa Tuwel tahun 2020

\begin{tabular}{lcc}
\hline $\begin{array}{l}\text { Kemungkinan Teknologi } \\
\text { Instore Dryer dicoba dalam } \\
\text { skala kecil }\end{array}$ & $\mathrm{n}$ & $\%$ \\
\hline Tidak mungkin dicoba & 0 & 0 \\
Kurang mungkin di coba & 30 & 69.8 \\
Sangat mungkin di coba & 13 & 30.2 \\
\hline Total & 43 & 100 \\
\hline
\end{tabular}

\section{Tingkat Kemungkinan diamati}

Berdasarkan data pada tabel 6 , sebanyak 41 responden mengetahui hasil penerapan inovasi dengan melihat indikator lama pengeringan dan hasil kering yang dapat dihitung dan diamati oleh petani responden. Keunggulan hasil pengeringan menggunakan Teknologi Instore Dryer sesuai dengan informasi yang disampaikan penyuluh dan/atau pemerintah saat Teknologi Instore Dryer resmi diberikan kepada petani Desa Tuwel.

Tabel 6 Jumlah dan persentase kemungkinan Teknologi Instore Dryer untuk diamati diDesa Tuwel tahun 2020

\begin{tabular}{lcc}
\hline Kemungkinan Teknologi & $\mathrm{n}$ & $\%$ \\
$\begin{array}{l}\text { Instore Dryer diamati } \\
\text { Tidak teramati }\end{array}$ & 0 & 0 \\
Kurang teramati & 2 & 4.7 \\
Sangat teramati & 41 & 95.3 \\
\hline Total & 43 & 100.0 \\
\hline
\end{tabular}

\section{ANALISIS PERAN PENYULUH PERTANIAN}

Peran penyuluh yang ditetiliti adalah peran sebagai pendidik, konsultan, pendorong, pendamping, dan fasilitator. Berdasarkan penilaian responden, penyuluh setempat sudahmemenuhi perannya untuk menunjang aktivitas petani . Mayoritas responden, penyuluh sudah sangat berperan sebagai pendidik bagi para petani. Peran penyuluh yang dirasakan petani antara lain penyuluh mampu menyampaikan materi-materi seputar pertanian bawang putih. Responden yang menilai penyuluh kurang berperan sebagai pendidik petani adalah responden yang tidak selalu mengikuti agenda pertemuan dan/atau petani yang sekadar datang ke pertemuan tanpa memperhatikan materi atau hanya ikut petani lainnya untuk meramaikan pertemuan. Data menunjukkan penyuluh sangat berperan sebagai konsultan bagi petani responden. Peran aktif penyuluh sebagai konsultan dilihat dari penyuluh di Desa Tuwel yang sering mendatangi petani dan bertanya langsung di tempat bagaimana perkembangan kegiatan bertani yang dijalankan oleh responden, sehingga sering terjalin komunikasi tanya jawab secara interpersonal antara penyuluh dengan petani. Petani yang menilai penyuluh kurang berperan sebagai seorang konsultan bagi petani adalah responden dengan hubungan interpersonal yang tidak begitu intensif dan dekat. Jumlah dan persentase responden berdasarkan peran penyuluh dapat dilihat pada Tabel 7. 
Tabel 7 Jumlah dan persentase penilaian responden terhadap peran penyuluh di Desa Tuwel 2020

\begin{tabular}{|c|c|c|c|}
\hline \multirow{2}{*}{\multicolumn{2}{|c|}{ Peran Penyuluh }} & \multicolumn{2}{|c|}{ Responden } \\
\hline & & $\mathrm{n}$ & $\%$ \\
\hline \multirow[t]{3}{*}{ Pendidik } & Tidak berperan & 0 & 0 \\
\hline & Kurang berperan & 5 & 11.6 \\
\hline & Sangat berperan & 38 & 88.4 \\
\hline Total & & 43 & 100 \\
\hline \multirow{3}{*}{ Konsultan } & Tidak berperan & 0 & 0 \\
\hline & Kurang berperan & 3 & 7 \\
\hline & Sangat berperan & 40 & 93 \\
\hline Total & & 43 & 100 \\
\hline \multirow[t]{3}{*}{ Pendorong } & Tidak berperan & 0 & 0 \\
\hline & Kurang berperan & 7 & 16.3 \\
\hline & Sangat berperan & 36 & 83.7 \\
\hline \multirow[t]{3}{*}{ Total } & & 43 & 100 \\
\hline & & & \\
\hline & Peran Penyulun & $\mathrm{n}$ & $\%$ \\
\hline \multirow[t]{3}{*}{ Pendamping } & Tidak berperan & 0 & 0 \\
\hline & Kurang berperan & 18 & 41.9 \\
\hline & Sangat berperan & 25 & 58.1 \\
\hline Total & & 43 & 100 \\
\hline \multirow[t]{3}{*}{ Fasilitator } & Tidak berperan & 0 & 0 \\
\hline & Kurang berperan & 23 & 53.5 \\
\hline & Sangat berperan & 20 & 46.5 \\
\hline Total & & 43 & 100 \\
\hline
\end{tabular}

Data juga menunjukkan bahwa mayoritas petani responden $(83.7 \%)$ beranggapan penyuluh pertanian di Desa Tuwel sangat berperan sebagai seorang pendorong/motivator. Penyuluh dinilai giat mengingatkan agar terus semangat untuk menjadikan Desa Tuwel sebagai sentra bawang putih di Jawa Tengah sebagaimana yang pernah terjadi di masa lampau.

Penyuluh setempat diniliai sudah berperan dalam mendampingi petani ketika bertemu dengan pihak eksternal kelompok tani seperti perusahaan importir, dinas pertanian, atau pihak-pihak lainnya. Petani responden relatif menganggap penyuluh sangat berperan sebagai pendamping petani. Petani yang menganggap penyuluh sangat berperan sebagai pendamping merupakan petani yang aktif mengikuti kegiatan yang diadakan oleh kelompok tani, dinas pertanian, pemerintah kabupaten, atau pihak lainnya. Perbandingan responden yang menilai penyuluh kurang berperan sebagai fasilitator dan yang menilai penyuluh sangat berperan hampir sama, yaitu 23:20 responden. Lebih banyak responden menilai penyuluh kurang berperan sebagai fasilitator. Responden yang menilai penyuluh kurang berperan merupakan petani yang mengikuti berbagai pelatihan dan penjelasan mengenai Teknologi Instore Dryer saat peluncuran, akan tetapi tidak menerima materi secara langsung karena kurang efektifnya penyampaian materi. Berdasarkan analisis, hal ini kembali lagi kepada bagaimana intensitas petani berinteraksi dengan penyuluh.

\section{TAHAPAN PROSES PENGAMBILAN KEPUTUSAN ADOPSI INOVASI TEKNOLOGI INSTORE DRYER}

\section{Tahap Pengenalan}

Teknologi Instore Dryer diperkenalkan kepada petani di Desa Tuwel pada Bulan November tahun 2019 melalui Kementerian Pertanian Indonesia di bawah proyek Balai Besar Pascapanen sebagai bentuk hibah dari Kementerian Pertanian. Berdasarkan Tabel 8, sebagian besar petani (27 responden) telah mengenal Teknologi Instore Dryer pada bulan November 2019, yaitu ketika diadakannya peresmian dan sosialisasi kepada petani. 
Tabel 8 Jumlah dan persentase penilaian responden berdasarkan waktu mengenal inovasi di Desa Tuwel 2020

\begin{tabular}{lcc}
\hline Waktu Petani Mengenal & $\mathrm{n}$ & $\%$ \\
\hline$<$ November 2019 & 0 & 0 \\
November 2019 & 27 & 62.8 \\
Saat dilakukannya & 16 & 37.2 \\
wawancara & & 100 \\
\hline Total & 43 & \\
\hline
\end{tabular}

Merujuk kepada teori Rogers (2003) mengenai bagaimana suatu inovasi dikomunikasikan melalui saluran tertentu, petani Desa Tuwel terbagi menjadi dua karakteristik dalam mengenal Teknologi Instore Dryer, yaitu petani yang langsung mengenal melalui demonstrasi pada Bulan November 2019 dan petani yang mengenal melalui komunikasi interpersonal. Berdasarkan temuan lapang pengetahuan tentang penggunaan Teknologi Instore Dryer yang dimiliki petani di Desa Tuwel tergolong dalam kategori tinggi. Tabel 9 menunjukkan jumlah dan persentase pengetahuan responden mengenai Teknologi Instore Dryer.

Tabel 9 Jumlah dan persentase pengetahuan responden mengenai Teknologi Instore Dryer di Desa Tuwel 2020

\begin{tabular}{lcc}
\hline Pengetahuan mengenai & $\mathrm{n}$ & $\%$ \\
Teknologi Instore Dryer & & 37.2 \\
Rendah & 16 & 4.6 \\
Sedang & 2 & 58.2 \\
Tinggi & 25 & 100.0 \\
\hline Total & 43 & \\
\hline
\end{tabular}

Adapun petani dengan tingkat pengenalan yang rendah merupakan petani yang yang baru mengetahui adanya Teknologi Instore Dryer saat dilakukannya penelitian juga mengungkapkan ingin mengetahui dan mencobanya jika ada kesempatan.

\section{Tahap Persuasi}

Tingkat ketertarikan petani terhadap Teknologi Instore Dryer dapat dikatakan signifikan antara tingkat ketertarikan rendah, sedang, maupun tinggi. Tabel 10 menunjukkan jumlah dan persentase persepsi responden berdasarkan ketertarikan terhadap Teknologi Instore Dryer.

Tabel 10 Jumlah dan persentase ketertarikan responden mengenai Teknologi Instore Dryer di Desa Tuwel 2020

\begin{tabular}{lcc}
\hline Ketertarikan terhadap & $\mathrm{n}$ & $\%$ \\
Teknologi Instore Dryer & & 30.2 \\
\hline Rendah & 13 & 37.2 \\
Sedang & 15 & 32.6 \\
Tinggi & 14 & 100 \\
\hline Total & 43 & \\
\hline
\end{tabular}

Penyebab ketertarikan yang rendah adalah sulitnya mekanisme penggunaan Teknologi Instore Dryer untuk mengeringkan hasil panen pribadi atau kelompok kecil, karena penggunaan inovasi lebih diperuntukkan untuk hasil panen kelompok tani. Kelebihan yang paling sering disebutkan oleh responden adalah kemampuan Teknologi Instore Dryer untuk mengeringkan umbi bawang putih dengan waktu yang lebih singkat, terutama apabila memasuki musim panen pada musim hujan. 


\section{Tahap Keputusan}

Berdasarkan data hasil temuan lapang pada Tabel 11, seluruh responden memutuskan untuk menerima Teknologi Instore Dryer sebagai inovasi yang dapat membantu petani mengeringkan hasil panen bawang putih.

Tabel 11 Jumlah dan persentase pengambilan keputusan responden mengenai Teknologi Instore Dryer di Desa Tuwel 2020

\begin{tabular}{lcc}
\hline $\begin{array}{l}\text { Pengetahuan mengenai } \\
\text { Teknologi }\end{array}$ & $\mathrm{n}$ & $\%$ \\
Dryer & & \\
\hline Menolak & 0 & 0.0 \\
Menerima & 43 & 100 \\
\hline Total & 43 & 100 \\
\hline
\end{tabular}

Adapun tanggapan dari petani responden yang baru mengetahui informasi mengenai adanya Teknologi Instore Dryer di Desa Tuwel ketika diadakannya penelitian, mengaku ingin melihat bagaimana proses penggunaan mesin tersebut.

\section{Tahap Penerapan}

Berdasarkan data Tabel 12, tidak semua petani dapat langsung mengetahui mekanisme atau proses penggunaan Teknologi Instore Dryer untuk mengeringkan hasil panen petani. Hal ini disebabkan penggunaan Teknologi Instore Dryer ditujukan untuk mengeringkan hasil panen kelompok dan penerapannya hanya dilakukan oleh petani yang ditugaskan kelompok. Data memberi garis besar temuan lapang, bahwa Teknologi Instore Dryer sudah diterapkan untuk hasil panen kelompok tani namun belum diterapkan oleh seluruh petani untuk mengeringkan hasil panennya.

Tabel 12 Jumlah dan persentase penerapan Teknologi Instore Dryer oleh responden di Desa Tuwel 2020

\begin{tabular}{lcc}
\hline $\begin{array}{l}\text { Penerapan Teknologi } \\
\text { Instore Dryer }\end{array}$ & $\mathrm{n}$ & $\%$ \\
\hline Tidak Menerapkan & 27 & 62.8 \\
Menerapkan & 16 & 37.2 \\
\hline Total & 43 & 100.0 \\
\hline
\end{tabular}

\section{Tahap Konfirmasi}

Berdasarkan perbandingan Tabel 11 dengan Tabel 12, data menunjukkan mayoritas petani (27 responden) tidak menerapkan Teknologi Instore Dryer dalam kegiatan panennya. Jumlah dan persentase responden berdasarkan konfirmasi atau penguatan informasi dapat dilihat pada Tabel 13.

Tabel 13 Jumlah dan persentase responden pada tahap konfirmasi adopsi Teknologi Instore Dryer oleh responden di Desa Tuwel 2020

\begin{tabular}{lcc}
\hline $\begin{array}{l}\text { Konfirmasi adopsi oleh } \\
\text { petani }\end{array}$ & $\mathrm{n}$ & $\%$ \\
\hline Rendah & 16 & 37.2 \\
Sedang & 6 & 14.0 \\
Tinggi & 21 & 48.8 \\
\hline Total & 43 & 100.0 \\
\hline
\end{tabular}

Hal ini menunjukkan petani bawang putih di Desa Tuwel, baik yang menerapkan inovasi saat panen atau tidak, telah melakukan konfirmasi mengenai inovasi tersebut. Konfirmasi yang dilakukan oleh petani yang tidak menerapkan inovasi pada kegiatan pascapanennya, 
menunjukkan adanya peluang bagi petani untuk ingin menerapkan inovasi seperti petani yang sudah menerapkan inovasi. Adapun responden yang memiliki tingkat penguatan informasi yang rendah merupakan petani yang baru mengenal Teknologi Instore Dryer ketika penelitian dilaksanakan.

Tabel 14 menunjukkan jumlah dan persentase responden berdasarkan sumber penguatan informasi.

Tabel 14 Jumlah dan persentase sumber penguatan informasi responden terhadap Teknologi Instore Dryer oleh responden di Desa Tuwel 2020

\begin{tabular}{lcc}
\hline $\begin{array}{l}\text { Sumber Penguatan } \\
\text { informasi mengenai }\end{array}$ & $\mathrm{n}$ & $\%$ \\
$\begin{array}{l}\text { Teknologi Instore } \\
\text { Dryer }\end{array}$ & & \\
\hline Akademisi/llmuwan & 6 & 14 \\
Rekan & 37 & 86 \\
Tani/Penyuluh & & \\
\hline Total & 43 & 100.0 \\
\hline
\end{tabular}

\section{FAKTOR-FAKTOR YANG BERHUBUNGAN DENGAN PENGAMBILAN KEPUTUSAN ADOPSI TEKNOLOGI INSTORE DRYER}

\section{Hubungan antara Karakteristik Petani dengan Tahap Pengenalan Petani terhadap Teknologi Instore Dryer}

Peubah-peubah yang diuji untuk menguji hubungan antarvariabel terdiri dari umur, tingkat pendidikan, intensitas mengikuti penyuluhan, luas penggunaan lahan, status kepemilikan lahan, tingkat pendapatan, dan sumber informasi petani. Tabel 15 menyajikan informasi hubungan antarvariabel.

Tabel 15 Nilai koefisien korelasi antara karakteristik individu dengan tingkat pengenalan petani terhadap Teknologi Instore Dryer di Desa Tuwel 2020

\begin{tabular}{|c|c|c|}
\hline \multirow{2}{*}{$\begin{array}{l}\text { Karakteristik } \\
\text { individu }\end{array}$} & \multicolumn{2}{|c|}{ Tahap pengenalan petani terhadap Teknologi Instore Dryer } \\
\hline & Koef & Sig \\
\hline Umur & 0.020 & 0.896 \\
\hline $\begin{array}{l}\text { Tingkat Pendidikan } \\
\text { Intensitas }\end{array}$ & -0.022 & 0.888 \\
\hline $\begin{array}{l}\text { Mengikuti } \\
\text { Penyuluhan }\end{array}$ & $0.365 * *$ & 0.016 \\
\hline Karakteristik & \multicolumn{2}{|c|}{ Tahap pengenalan petani terhadap Teknologi Instore Dryer } \\
\hline individu & Koef & Sig \\
\hline $\begin{array}{l}\text { Luas Penggunaan } \\
\text { Lahan }\end{array}$ & 0.172 & 0.271 \\
\hline $\begin{array}{l}\text { Status Kepemilikan } \\
\text { Lahan }\end{array}$ & 0.136 & 0.386 \\
\hline Tingkat Pendapatan & 0.025 & 0.872 \\
\hline Sumber Informasi & 0.080 & 0.610 \\
\hline
\end{tabular}

Keterangan: ${ }^{* *} \alpha=0.05$ (nyata)

Berdasarkan data penelitian, hanya satu variabel karakteristik individu yang menunjukkan adanya hubungan nyata dengan tahap pengenalan petani terhadap Teknologi Instore Dryer, yaitu variabel intensitas mengikuti penyuluhan. Semakin sering petani mengikuti penyuluhan, maka akan semakin memberikan kesempatan kepada petani untuk mengetahui berbagai 
informasi seputar pertanian, termasuk informasi mengenai adanya inovasi Teknologi Instore Dryer. Fakta tersebut serupa dengan hasil penelitian Indraningsih (2011) yang menyatakan petani Cianjur-Garut akan mengenal adanya Teknologi Usahatani Terpadu ketika ia mengikuti penyuluhan yang diadakan.

Hubungan pada enam variabel lainnya adalah hubungan yang bersifat tidak nyata. Umur petani tidak menunjukkan adanya hubungan dengan tahap pengenalan inovasi. Hal ini terjadi karena Teknologi Instore Dryer diperkenalkan oleh Balai Pascapanen secara kolektif dan menghadirkan petani dari berbagai kalangan usia. Tinggi dan beragamnya tingkat pendidikan formal petani tidak menunjukkan hubungan dengan tahap pengenalan. Hal ini dapat terjadi karena petani mendapat informasi secara langsung mengenai Teknologi Instore Dryer ketika adanya sosialisasi. Temuan lapang juga sejalan dengan hasil penelitian Rahmi (2019) mengenai tingkat pendidikan formal petani Desa Pasir Eurih yang tidak memiliki hubungan dengan inovasi sistem jajar legowo.

Luas penggunaan lahan tidak menunjukkan danya hubungan dengan tahap pengenalan Teknologi Instore Dryer. Hal serupa juga terdapat pada variabel status kepemilikan lahan. Demikian terjadi, karena 70 persen hasil panen petani yang dihasilkan dari garapan dan kepemilikan lahan petani langsung dilimpahkan kepada kelompok tani untuk kemudian dibeli oleh importir (perusahaan), kemudian dikeringkan dengan inovasi yang ada. Tingkat pendapatan petani juga tidak menunjukkan adanya hubungan dengan pengenalan inovasi. Artinya, rendah atau tingginya tingkat pendapatan atau bagaimana keadaan ekonomi petani tidak mempengaruhi keingintahuan petani untuk mengenal inovasi bagi pertanian bawang putih. Temuan ini berbanding terbalik dengan penelitian Rahmi (2019) yang menyatakan petani Desa Pasir Eurih yang memiliki pendapatan tinggi, akan lebih mudah untuk mengalokasikan uang yang dimiliki untuk mengimplementasikan inovasi tanam jajar legowo sebagai suatu hal yang patut dicoba dan dianggap dapat menguntungkan.

\section{Hubungan antara Peran Penyuluh dengan Tahap Pengenalan Petani terhadap Teknologi Instore Dryer}

Peran penyuluh pertanian juga menjadi variabel independen yang memiliki hubungan dengan tahap pengenalan petani terhadap Teknologi Instore Dryer. Hasil uji korelasi menunjukkan terdapat tiga variabel yang menunjukkan adanya hubungan dengan tahap pengenalan, yang terdiri dari pendidik, pendorong, dan pendamping petani. Peran penyuluh sebagai pendidik memberikan kesempatan kepada petani untuk mendapatkan informasi mengenai Teknologi Instore Dryer. Hal ini didukung dengan analisis hubungan variabel intensitas mengikuti penyuluhan petani sebelumnya (Tabel 15) yang memiliki hubungan nyata dengan tahap pengenalan Teknologi Instore Dryer. Tabel 16 menunjukkan gambaran antarvariabel yang diuji dengan korelasi Rank Spearman.

Tabel 16 Nilai koefisien korelasi antara peran penyuluh dengan tingkat pengenalan petani terhadap Teknologi Instore Dryer di Desa Tuwel 2020

\begin{tabular}{lcc}
\hline \multirow{2}{*}{ Peran Penyuluh } & \multicolumn{2}{c}{ Tahap pengenalan petani terhadap Teknologi Instore Dryer } \\
\cline { 2 - 3 } & Koef & Sig \\
\hline Pendidik & 0.267 & $0.084^{*}$ \\
Konsultan & 0.148 & 0.344 \\
Pendorong & 0.260 & $0.092^{*}$ \\
Pendamping Petani & 0.276 & $0.073^{*}$ \\
Fasilitator & -0.051 & 0.744 \\
\hline
\end{tabular}

Keterangan: $* \alpha=0.1$ (nyata)

Penyuluh sebagai pendorong atau motivator juga menjadi jalan untuk mengenalkan inovasi kepada petani. Peran penyuluh sebagai pendamping petani juga sangat mendukung dapat 
dikenalnya Teknologi Instore Dryer, karena ketika adanya sosialisasi pengenalan inovasi, penyuluh membantu petani untuk memahami materi yang disampaikan oleh pihak Balai Penelitian Pascapanen. Hal ini serupa dengan hasil penelitian Vinelly (2018) yang menyatakan peran penyuluh sebagai pendidik dan pemberi penjelasan mampu untuk mengenalkan inovasi Rice Transplanter kepada kelompok tani di Madiun.

\section{Hubungan antara Peran Penyuluh dan Tahap Pengenalan dengan Tahap Persuasi Petani terhadap Teknologi Instore Dryer}

Berdasarkan hasil penelitian, peran penyuluh yang memiliki hubungan dengan tahap persuasi adalah peran konsultan dan pendamping petani. Peran pendidik, pendorong, dan fasilitator memiliki hubungan yang tidak nyata terhadap tahap persuasi. Ketika penyuluh memberikan informasi Teknologi Instore Dryer, sangat mungkin apabila dalam penyampaiannya tidak menimbulkan suatu persepsi di kalangan petani. Penyuluh tidak menjadikan aktivitas memersuasi kembali terkait adanya Teknologi Instore Dryer menjadi fokusnya ketika menjalankan tugasnya menjadi pendorong dan fasilitator. Adapun tahap pengenalan menunjukkan hubungan yang sangat nyata. Artinya semakin petani mengenal Teknologi Instore Dryer maka petani semakin memiliki persepsi mengenai inovasi tersebut dan tertarik untuk menggunakannya. Hal ini sesuai dengan penelitian Rahmi (2019) yang menunjukkan adanya hubungan nyata antara tingkat pengetahuan dengan tingkat persepsi petani di Desa Pasir Eurih. Tabel 17 menunjukkan korelasi peran penyuluh dan tahap pengenalan terhadap tahap persuasi Teknologi Instore Dryer.

Tabel 17 Nilai koefisien korelasi antara peran penyuluh dengan tingkat pengenalan petani terhadap Teknologi Instore Dryer di Desa Tuwel 2020

\begin{tabular}{|c|c|c|}
\hline \multirow{2}{*}{ Variabel } & \multicolumn{2}{|c|}{ Tahap persuasi petani terhadap Teknologi Instore Dryer } \\
\hline & Koef & Sig \\
\hline $\begin{array}{ll}\text { Penyuluh } & \text { Sebagai } \\
\text { Pendidik } & \end{array}$ & 0.199 & 0.201 \\
\hline $\begin{array}{l}\text { Penyuluh Sebagai } \\
\text { Konsultan }\end{array}$ & $0.385^{* *}$ & 0.011 \\
\hline $\begin{array}{l}\text { Penyuluh Sebagai } \\
\text { Pendorong }\end{array}$ & 0.189 & 0.224 \\
\hline $\begin{array}{l}\text { Penyuluh Sebagai } \\
\text { Pendamping Petani }\end{array}$ & $0.306^{* *}$ & 0.046 \\
\hline $\begin{array}{l}\text { Penyuluh Sebagai } \\
\text { Fasilitator }\end{array}$ & 0.080 & 0.612 \\
\hline Tahap Pengenalan & $0.500 * * *$ & 0.001 \\
\hline
\end{tabular}

Keterangan: $* * \alpha=0.05$ (nyata)

$* * * \alpha=0.01$ (sangat nyata)

\section{Hubungan antara Peran Penyuluh dan Tahap Persuasi dengan Tahap Keputusan Petani terhadap Teknologi Instore Dryer}

Berdasarkan hasil uji analisis, empat variabel peran penyuluh tidak memiliki hubungan dengan tahap keputusan petani, kecuali pada peran penyuluh sebagai pendidik. Tabel 18 menyajikan nilai koefisien dan signifikansi korelasi antara peran penyuluh dan tahap persuasi dengan tahap keputusan petani. 
Tabel 18 Nilai koefisien korelasi antara peran penyuluh dan tahap persuasi dengan tahap keputusan petani terhadap Teknologi Instore Dryer di Desa Tuwel 2020

\begin{tabular}{lll}
\hline Variabel & \multicolumn{2}{c}{ Tahap keputusan petani terhadap Teknologi Instore Dryer } \\
\cline { 2 - 3 } $\begin{array}{l}\text { Penyuluh Sebagai } \\
\text { ndidik }\end{array}$ & 0.282 & Sig \\
$\begin{array}{l}\text { Penyuluh Sebagai } \\
\text { nsultan }\end{array}$ & -0.050 & 0.067 \\
$\begin{array}{l}\text { Penyuluh Sebagai } \\
\text { ndorong }\end{array}$ & -0.061 & 0.751 \\
$\begin{array}{l}\text { Penyuluh Sebagai } \\
\text { ndamping Petani }\end{array}$ & -0.088 & 0.696 \\
$\begin{array}{l}\text { Penyuluh Sebagai } \\
\text { silitator }\end{array}$ & -0.240 & 0.574 \\
Tahap Persuasi & $0.426^{* * *}$ & 0.120 \\
\hline
\end{tabular}

Keterangan: *** $\alpha=0.01$ (sangat nyata)

Petani merasa tidak terdorong dan memiliki kemauan untuk memutuskan melakukan penggunaan inovasi ketika penyuluh lapang menjalankan perannya. Terkecuali pada peran penyuluh sebagai pendidik yang memiliki hubungan nyata. Hal ini serupa dengan penelitian Vinelly (2018) yang menyatakan tingginya peran penyuluh sebagai pendidik berhubungan dengan keputusan petani untuk melakukan adopsi inovasi. Dalam penelitian yang sama, hal tersebut berbanding terbalik pada variabel peran penyuluh sebagai pendamping petani. Vinelly (2018) menyimpulkan dari penelitiannya penyuluh sebagai pendamping petani akan mempengaruhi petani untuk melakukan adopsi inovasi Rice Transplanter pada Kelompok Tani. Tahap persuasi menunjukkan signifikansi hubungan yang sangat nyata antara tahap persuasi dengan tahap keputusan petani terhadap Teknologi Instore Dryer. Hal ini menunjukkan semakin tinggi sikap petani untuk mau menerima unsur-unsur penggunaan Teknologi Instore Dryer maka akan semakin tinggi kemauan petani untuk memutuskan melakukan adopsi inovasi. Petani merasa perlu melakukan pembuktian informasi-informasi mengenai Teknologi Instore Dryer, sehingga petani memberikan keputusan untuk menggunakan Teknologi Instore Dryer.

\section{Hubungan antara Peran Penyuluh dan Tahap Keputusan dengan Tahap Implementasi Petani terhadap Teknologi Instore Dryer}

Berdasarkan hasil penelitian, nilai koefisien masing-masing variabel peran penyuluh menunjukkan sifat hubungan yang tidak nyata dengan tahap implementasi. Peran penyuluh sebagai pendidik, konsultan, pendorong, pendamping petani, dan fasilitator memiliki hubungan yang tidak nyata dengan tahap implementasi petani. Makna data menunjukkan semakin tingginya peran penyuluh berdasarkan masing-masing variabel tidak menjadikan penggunaan inovasi semakin tinggi. Hal ini terjadi karena alasan petani di Desa Tuwel menggunakan Teknologi Instore Dryer adalah karena status Teknologi Instore Dryer yang merupakan hibah dari pemerintah, sehingga perlu untuk digunakan sebagai sinergitas antara kelompok tani dengan pihak Kementerian Pertanian (Balai Penelitian Pascapanen). Korelasi antara tahap pengambilan keputusan dengan tahap implementasi menunjukkan hubungan yang signifikan. Makna dari hubungan tersebut adalah semakin tingginya keputusan petani untuk mengadopsi Teknologi Instore Dryer akan mendorong petani untuk semakin menggunakannya. Hasil hubungan antarvariabel ditunjukkan pada Tabel 19. 
Tabel 19 Nilai koefisien korelasi antara peran penyuluh dan tahap keputusan dengan tahap implementasi petani terhadap Teknologi Instore Dryer di Desa Tuwel 2020

\begin{tabular}{|c|c|c|}
\hline \multirow{2}{*}{ Variabel } & \multicolumn{2}{|c|}{ Tahap implementasi petani terhadap Teknologi Instore Dryer } \\
\hline & Koef & Sig \\
\hline Penyuluh & \multirow{2}{*}{0.215} & 0.167 \\
\hline Sebagai Pendidik & & \\
\hline Penyuluh & \multirow{3}{*}{0.242} & 0.103 \\
\hline Sebagai & & \\
\hline Konsultan & & \\
\hline Penyuluh & \multirow{3}{*}{0.200} & 0.198 \\
\hline Sebagai & & \\
\hline Pendorong & & \\
\hline Penyuluh & \multirow{4}{*}{0.066} & 0.676 \\
\hline Sebagai & & \\
\hline Pendamping & & \\
\hline Petani & & \\
\hline Penyuluh & \multirow{3}{*}{-0.181} & 0.246 \\
\hline Sebagai & & \\
\hline Fasilitator & & \\
\hline Tahap Keputusan & 0.284 & $0.065^{*}$ \\
\hline
\end{tabular}

Keterangan: $* \alpha=0.1$ (nyata)

Temuan lapang menunjukkan seluruh petani mengambil keputusan untuk menerima inovasi atas nama kelompok tani, akan tetapi tidak semua petani dapat mengimplementasikan inovasi tersebut ketika panen. Hal ini serupa dengan penelitian Indraningsih (2011) mengenai petani Cianjur dan Garut yang telah mengadopsi inovasi usahatani terpadu dengan pengambilan keputusannya dilakukan oleh pengurus kelompok tani secara informal, akan tetapi mewakili seluruh anggota kelompok tani yang diwakilkan oleh kelompok tani.

\section{Hubungan antara Peran Penyuluh dan Tahap Implementasi dengan Tahap Konfirmasi Petani terhadap Teknologi Instore Dryer}

Berdasarkan hasil penelitian, peran konsultan menunjukkan hubungan yang nyata. Artinya semakin penyuluh berperan sebagai konsultan akan menjadikan tingginya konfirmasi petani untuk mengetahui lebih banyak lagi informasi penggunaan Teknologi Instore Dryer. Tabel 20 menunjukkan hubungan antarvariabel melalui uji korelasi Rank Spearman. 
Tabel 20 Nilai koefisien korelasi antara peran penyuluh dan tahap implementasi dengan tahap konfirmasi petani terhadap Teknologi Instore Dryer di Desa Tuwel 2020

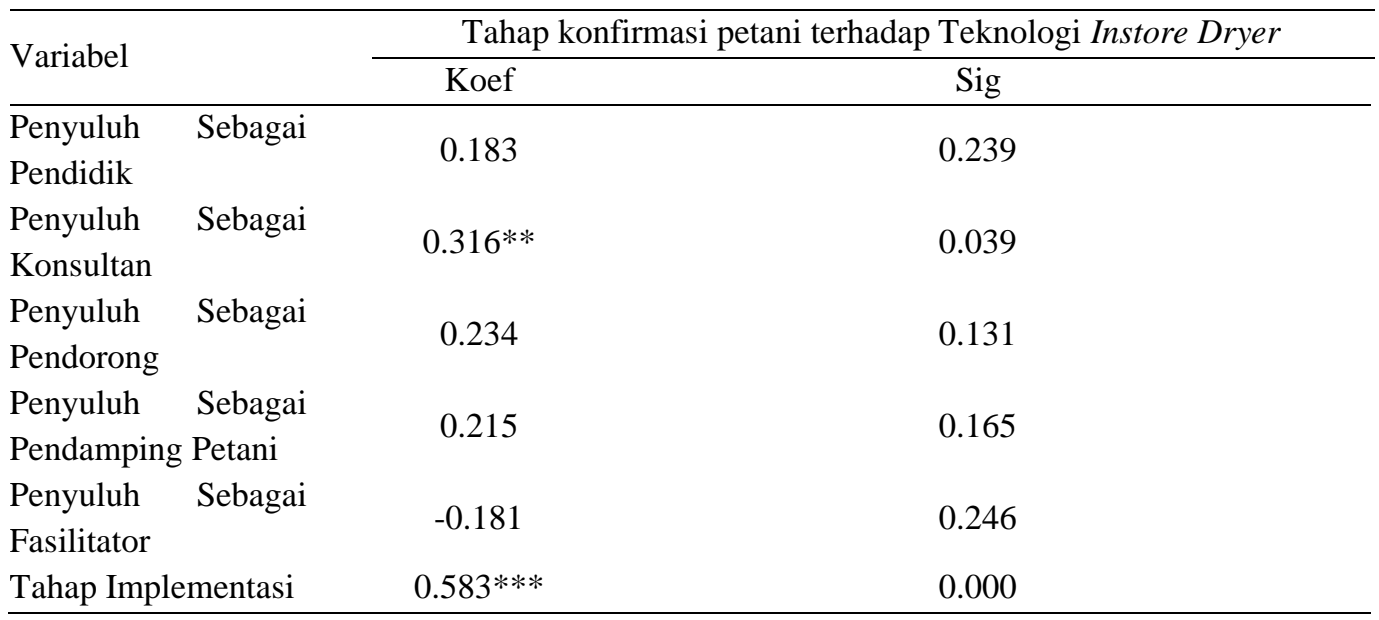

Keterangan: $* * \alpha=0.05$ (nyata)
$* * * \alpha=0.01$ (sangat nyata)

Tahap implementasi menunjukkan hubungan yang sangat nyata dengan tahap konfirmasi adalah hubungan yang sangat nyata. Dapat diartikan petani yang sudah berkesempatan untuk menggunakan Teknologi Instore Dryer pasti melakukan konfirmasi untuk memperkuat keputusannya. Selain itu, petani juga sudah dapat membandingkan hasil pengeringan bawang putih tanpa menggunakan inovasi dan dengan menggunakannya, dengan begitu petani dapat memiliki pengalaman dan pengetahuan yang dapat dikonfirmasi untuk memutuskan apakah akan meneruskan menerapakan inovasi atau tidak. Peran pendidik, pendorong, dan pendamping petani menunjukkan keempat variabel tersebut memiliki hubungan yang tidak nyata.

\section{PENUTUP}

Adapun kesimpulan dalam penelitian ini adalah: (1) Hasil penelitian menunjukkan pengambilan keputusan adopsi inovasi Teknologi Instore Dryer di Desa Tuwel, Kecamatan Bojong, Kabupaten Tegal dilakukan secara kolektif oleh petani setempat melalui keputusan kelompok tani. Penerapan inovasi belum sepenuhnya dilakukan oleh setiap anggota kelompok tani, inovasi hanya diimplementasikan oleh beberapa petani yang menjadi pengelola penggunaan Teknologi Instore Dryer; (2) Karakteristik petani yang memiliki hubungan sangat nyata dengan tahap pengenalan Teknologi Instore Dryer adalah intensitas mengikuti penyuluhan. Karakteristik petani lainnya yang terdiri dari usia, tingkat pendidikan formal, luas dan status kepemilikan lahan, tingkat pendapatan, dan sumber informasi tidak memiliki hubungan yang nyata dengan tahap pengenalan inovasi; (3) Penyuluh pertanian sudah dinilai berperan sebagai pendidik, konsultan, pendorong, pendamping petani, dan fasilitator bagi petani. Peran penyuluh sebagai pendidik, pendorong, dan pendamping petani menunjukkan hubungan dengan tahap pengenalan. Penyuluh sebagai konsultan dan pendamping petani menunjukkan hubungan yang sangat nyata dengan tahap persuasi. Adapun penyuluh sebagai pendidik merupakan satusatunya variabel yang memiliki hubungan dengan tahap pengambilan keputusan. Sementara itu tidak ada peran penyuluh yang berhubungan dengan tahap implementasi. Pada tahap konfirmasi, peran penyuluh sebagai konsultan memiliki hubungan yang sangat nyata dengan tahap konfirmasi; dan (3) Lima tahapan adopsi inovasi menunjukkan adanya hubungan yang nyata antar satu tahap dengan tahap selanjutnya. 


\section{Saran:}

Saran dari tindak lanjut penelitian ini adalah sebagai berikut: (1) Perlu adanya resosialisasi atau pengenalan dan demonstrasi kembali mengenai penggunaan Teknologi Instore Dryer secara masifkepada seluruh petani di Desa Tuwel. Salah satu cara yang disarankan adalah dengan pembentukan kelompok-kelompok kecil untuk melakukan transfer informasi secara fokus kepada petani, agar informasi dapat dipahami oleh petani secara merata; (2) Perlu adanya upaya untuk regulasi jadwal penggunaanTeknologiInstore Dryer untuk hasil panen personal anggota kelompok tani apabila memungkinkan untuk didiskusikan secara bersama; dan (3) Bagi peneliti selanjutnya yang melakukan penelitian ditempat yang sama tentang adopsi inovasi Teknologi Instore Dryer, disarankan untuk meneliti lebih lanjut bagaimana implementasi penerapan inovasi untuk pengeringan hasil panen pribadi petani apabila regulasi pada poin sebelumnya sudah terealisasi.

\section{DAFTAR PUSTAKA}

Amanda G. 2019 Nov 24. Tegal jadi lokasi pelatihan petugas verifikasi bawang putih. Republika. Rubrik Ekonom [Internet]. Tersedia pada: https://www.google. com/amp/s/m. republika. co. id/amp/q1g1ao423

Aditiawati P, Rosmiati, Dumardi D. 2014. Persepsi petani terhadap inovasi teknologi pestisida nabati limbah tembakau. Sosiohumaniora [Internet]. [Diunduh 2019 Nov 06]. 16(2); 184-192. Tersedia pada: https://doi. org/10.1007/978-3-319-67958-7

[Badan Litbangtan]. 2017. Badan Penelitian dan Pengembangan Pertanian 2017. Rencana Strategis Badan Penelitian dan Pengembangan Pertanian 2010-2014. Badan Litbang Pertanian. Jakarta (ID): Kementerian Pertanian.

[BPS] Badan Pusat Statistik. 2020. Kecamatan Bojong dalam Angka [Intemet]. [Dilihat pada 202021 Februari]. Tersedia pada: https://www. tegalkab. bps. go. id/publication. html

Indranigsih KS. 2011. Pengaruh penyuluhan terhadap keputusan petani dalam adopsi inovasi teknologi ushatani terpadu. Jurnal Agro Ekonomi [Internet]. [Diunduh 2020 Oktober 20]. 29(1):1-24. Tersedia pada: http://ejurnal. litbang. pertanian. go. id

[Kementerian Pertanian]. 2019. Rencana Strategis Kementerian Pertanian Tahun 2010-2014. Jakarta. Kementerian Pertanian

Mardikanto T. 2002. Redefinisi dan Revitalisasi Penyuluhan Pertanian. Surakarta (ID): Universitas Negeri Surakarta

Nugraha S, Adiandri RS, Yulianingsih. 2011. Pelayuan dan pengeringan bawang merah menggunakan instore drying untuk mempertahankan mutu dan mengurangi tingkat kerusakan. [Internet]. [Diunduh 2019 Des 20]. 8(2):72-81. Tersedia pada: http://ejurnal. litbang. pertanian. go. id/

Purba ER. 2015. Analisis karakteristik individu, perilaku komunikasi dan jenis media terhadap pemahaman petani tentang pupuk bersubsidi [Skripsi][Internet]. [Diunduh 2019 Des 18]. Tersedia pada :http://repository. usu. ac. $\mathrm{id} / \mathrm{bitstream} / \mathrm{handle} / 123456789 / 55135 /$ Chapterpersen20II. pdf? sequence $=4 \&$ is Allowed $=\mathrm{y}$

Putra E, Witjaksono P, Harsoyo. 2016. Peran ketua kelompok tani dalam adopsi teknologi budi daya bawang merah di lahan pasir pantai kecamatan sanden kabupaten bantul. Jurnal Agroekonomi [Internet]. [Diunduh 2019 Okt 19]. 27(2); 150-164. Tersedia pada: https://doi. org/10.22146/jae.22746

Putra S. 2016. Peran penyuluh pertanian dalam pengembangan kelompok tani padi sawah di Desa Rambah Baru Kecamatan Rambah Samo Kabupaten Rokan Hulu [Artikel Ilmiah] [Internet]. [Diunduh 2019 Des 17]. Tersedia pada: https://media. neliti. com/media/publications/108732-ID-peran-penyuluh-pertanian-dalam-pengemban. pdf 
Rahmi L. 2019. Pengambilan keputusan inovasi sistem jajar legowo di Desa Pasir Eurih, KecamaanTamansari, Kabupaten Bogor. [Skripsi]. Bogor (ID): Institut Pertanian Bogor

Rogers EM. 2003. Diffusion of Innovations. Ed. 3. [Internet]. [Diunduh 2019 Des 01]. New York (US): Macmillan Publishing. Tersedia pada: http://teddykw2. files. wordpress. com/2012/07/everett-m-rogers-diffusion-of-innovatons. pdf.

Soekartawi. 1985. Adopsi teknologi mukibat pada usaha tani ketela pohon di Jawa Timur [Artikel Ilmiah]. Malang (ID): Universitas Brawijaya.

[UU] Undang-Undang Nomor 16 Tahun 2006 Tentang Sistem Penyuluhan Pertanian, Perikanan, dan Kehutanan [Internet]. [Diunduh 2019 Nov 06]. Tersedia pada: http://www. dpr. go. id/dokjdih/document/uu

Ulfa R. 2018. Analisis usahatani bawang putih (Allium sativum L) dan permasalahannya di Nagari SalayoTanang Bukit Sileh Kecamatan Lembang Jaya Kabupaten Solok [Skripsi]. [Internet]. [Diunduh 2019 Des 12]. Tersedia pada: http://scholar. unand. ac. id/36996/5/SkripsiFULLTEXT. pdf

Vinelly DA. 2018. Peran penyuluh dalam proses adopsi inovasi pemanfaatn rice transplanter pada Kelompok Tani Rantai Agung Desa Banaran Kecamatan Balerejo Kabupaten Malang. [Skripsi]. Malang (ID): Universitas Brawijaya. 